\title{
Sliding velocity fluctuations and subglacial hydrology over the last two decades on Argentière glacier, Mont Blanc area
}

\author{
CHRISTIAN VINCENT, ${ }^{1}$ LUC MOREAU ${ }^{2}$ \\ ${ }^{1}$ Laboratoire de Glaciologie et Géophysique de l'Environnement, UJF/CNRS, Grenoble, France \\ ${ }^{2}$ Edytem, CNRS, Université de Savoie, Chambéry, France \\ Correspondence: Christian Vincent <vincent@lgge.obs.ujf-grenoble.fr>
}

\begin{abstract}
The subglacial observatory beneath the Argentière glacier provides a rare opportunity to study the interactions between glacier sliding velocity and subglacial runoff. The sliding velocity has been monitored in this cavity almost continuously since 1997 and the resulting data indicate a decrease in annual sliding velocities over the last two decades. We found close relationships between annual surface velocity, sliding velocity and ice thickness. These relationships indicate that the ice-flow velocity changes do not depend on subglacial water runoff changes at the annual timescale. The seasonal magnitudes of sliding also show a decrease over the last two decades. At the seasonal timescale, sliding velocity increases before or simultaneously with the large runoff increase in May, indicating a distributed drainage system. Conversely, at the end of the melt season, sliding velocity continues to decrease after the runoff returns to low winter values. The simultaneous increases of runoff and sliding velocity occur mainly before the spring transition. Later, sliding velocity generally appears not to be related to water inputs coming from the surface, except for some large accelerations after midAugust that are always associated with periods of rapidly increasing water inputs to the subglacial drainage system.
\end{abstract}

KEYWORDS: glacier hydrology, ice velocity, mountain glaciers, sliding, subglacial processes

\section{INTRODUCTION}

Basal motion is a crucial component of the dynamic behavior of glaciers but is still a poorly understood aspect of glacier physics (e.g. Clarke, 1996; Fountain and Walder, 1998; Cuffey and Paterson, 2010). Understanding basal processes is a prerequisite to predicting the overall motion of a glacier and the response of this motion to climate change (e.g. Bartholomaus and others, 2008). For instance, basal motion is implicated in the recent acceleration of many Greenland outlet glaciers (Rignot and Kanagaratnam, 2006; Bartholomew and others, 2010, 2012; Schoof, 2010; Ryser and others, 2014).

A number of studies have shown that the basal water system affects a glacier's basal sliding motion (e.g. Bindschadler, 1983). Increased water pressures reduce the frictional drag and increase the sliding rate. In this way effective pressure, which is the difference between water pressure and pressure in the surrounding ice, decreases. Low effective pressures allow the formation of large cavities, which reduce the area of contact between the ice and bed (Lliboutry, 1968). The study of Harper and others (2007) revealed two separate modes of accelerated sliding during the annual spring increase of meltwater flux to the bed. The first mode is associated with increasing bed separation, likely due to the opening of cavities in the lee of bedrock bumps. The second mode is associated with a highly connected subglacial water network that presumably submerges much of the bed and transfers load to a diminished area of ice in contact with the bed (Harper and others, 2007). Conversely, basal sliding influences hydrology (Hoffman and Price, 2014). Such feedbacks remain poorly understood although they play a crucial role in seasonal variations of glacier flow (Cuffey and Paterson, 2010). Beneath glaciers with abundant summertime surface melt, water pressures and fluxes vary greatly in daily cycles and over seasons (e.g. Bartholomaus and others, 2008; Werder and others, 2013).

Previous theoretical studies have indicated two different subglacial drainage networks that directly affect sliding motion: an inefficient distributed system and an efficient channelized system that forms during periods of high discharge. The distributed system involves cavities that open behind bedrock bumps due to ice sliding, producing a socalled 'linked cavity system' (Walder, 1986; Kamb, 1987), or a water sheet of uniform thickness (Weertman, 1972; Flowers and Clarke, 2002; Creyts and Schoof, 2009), as well as permeable subglacial till (Shoemaker, 1986). On the other hand, channelized drainage involves conduits formed in the base of the ice by melting, known as Röthlisberberger (R) channels (Röthlisberger, 1972), or channels incised in the bedrock or sediments known as Nye channels (Nye, 1973).

The abundance of channels compared with cavity links determines whether the regionally averaged water pressure is low or high (Harper and others, 2007). The water pressure partly or totally counteracts the weight of the glacier, thus reducing the contact forces between the ice and the underlying rock. Consequently, the sliding motion depends on the subglacial drainage network. The sliding velocity will be low if the water under glaciers drains through channels at low pressure and high if the water drains through interconnected cavities at high pressure (e.g. Röthlisberger, 1972; Schoof, 2010).

Subglacial drainage evolves throughout the melt season. At the beginning of the melt season, the volume of stored water increases and water pressures build up. In this way, discharge from the distributed system with high pressure initially dominates (Pimentel and Flowers, 2010). This triggers an acceleration of the glacier. During the spring season, the channelized system develops progressively and conduit discharge 
with low pressure becomes predominant (Nienow and others, 1998). As a result, sliding velocity decreases.

Although many complex mathematical theories of sliding have been developed over recent decades (e.g. Kamb, 1970; Iken, 1981; Bindschadler, 1983; Fowler, 1987; Alley, 1989; Clarke, 2005; Pimentel and Flowers, 2010), the paucity of basal sliding observations has prevented any thorough validation of model studies.

Consequently, observations of basal motion and water flow at the glacier bed are greatly needed but are very difficult to obtain (Hantz and Lliboutry, 1983; Iken and others, 1983; Iken and Bindschaldler, 1986; Fischer and Clarke, 1994; Björnsson, 1998; Clarke, 2005). Basal velocity has been measured with different methods. Data relevant to sliding velocities have been obtained from the difference between the measured surface velocities and the internal deformation obtained from inclinometry (e.g. Hooke and others, 1992) or estimated from models (e.g. Hubbard and others, 1998; Mair and others, 2001). Further data have been obtained from direct observations in boreholes (e.g. Blake and others, 1994; Fischer and Clarke, 1994; Engelhardt and Kamb, 1998; Amundson and others, 2006; Ryser and others, 2014) but inserting sensors to great depths remains a difficult task. At several rare locations, tunnels excavated for hydroelectric projects provide access to glacier beds, allowing measurements in subglacial cavities and tunnels (Vivian, 1980; Moreau, 1995; Jansson and others, 1996; Cohen and others, 2000; Iverson and others, 2003; Lefeuvre and others, 2015). Basal velocities are very rarely measured simultaneously with ice thickness and runoff over long time periods.

The dataset of the subglacial observatory under the Argentière glacier is unique given that sliding velocities have been measured almost continuously since 1997 and continuously since 2000, along with the subglacial runoff during the melt season. The present study analyzes the relationships between sliding velocities, surface velocities, ice thickness and runoff at different timescales, from observations performed since 2000 in this subglacial observatory. The main goal of the present study is to document the fluctuations of sliding velocities at different timescales and provide insight into the relationships between sliding velocity, ice thickness and runoff.

\section{DATA AND METHODS}

Regular field measurements have been carried out by the LGGE (Laboratoire de Glaciologie et Géophysique de I'Environnement, Grenoble) since 1975 along four cross sections of the Argentière glacier $\left(45^{\circ} 10 \mathrm{~N} ; 6^{\circ} 10 \mathrm{E}\right)$ to measure the surface mass balance, surface ice-flow velocities and ice thickness changes (Vincent and others, 2009) (Fig. 1). Prior to the measurements, the annual mass balances were reconstructed using hypsometric and meteorological data (Vincent and others, 2009) (Fig. 2). The overall trend between 1905 and 2013 is constrained by glacier volume variations deduced from a map (1905) and aerial photographs (since 1949). In the vicinity of the subglacial observatory, the thickness change of cross section No. 4, located at $2400 \mathrm{~m}$ a.s.l. is measured annually (Fig. 3). For this purpose, topographic surveys using theodolite or GPS instruments have been performed to calculate the coordinates of 15-30 points on the cross section. Using these coordinates, the average elevation has been calculated for each year using the surface areas method in order to take into account the non-equidistant measurement spacing. The individual coordinates are obtained with an accuracy of a centimeter and the average is known with an accuracy of $15 \mathrm{~cm}$ (Vincent and others, 2009). The ice thickness in the vicinity of cross section No. 4 was measured using seismic reflection and validated in 24 boreholes (Reynaud, 1959; Hantz and Lliboutry, 1983). The bedrock topography obtained from seismic measurements is known with an average uncertainty of $\pm 10 \mathrm{~m}$ (Vincent and others, 2009) (Fig. 4). In addition, the surface ice-flow velocities have been measured on the same cross section using ablation stakes and painted stones located on the central flow line. These measurements are performed each year in September. Given the spatial variability of the ice-flow velocity, it is crucial to calculate the velocity at the same point each year. For this reason, since 1975, the stakes and stones have been relocated each year on a central flow line. The ice velocity at the intersection of this central flow line and the cross section is determined by interpolation with an accuracy of $\pm 0.15 \mathrm{~m} \mathrm{a}^{-1}$ (Vincent and others, 2009).

In addition, the hydroelectric power company Emosson $\mathrm{S}$. A. drilled numerous tunnels through the rock beneath the glacier in the 1970s to collect subglacial water. The water supplies the reservoir behind the dam of the Emosson company located $11 \mathrm{~km}$ away. Near these tunnels, a subglacial observatory has been set up at $2173 \mathrm{~m}$ a.s.l. to monitor the sliding movement continuously since 1997 (Moreau, 1995). The tunnels are located $850 \mathrm{~m}$ downstream of cross section No. 4 in an area with large seracs. Unfortunately, it is not possible to perform field measurements at the surface of the glacier just above this site in order to compare basal ice motion with surface ice-flow velocity. We can however compare these basal measurements with surface measurements performed at cross section No. 4. The sliding velocity is measured from a cavity that opens behind a bedrock bump using a 'cavitometer' designed by Vivian (1975). The cavitometer consists of a bicycle wheel with a circumference of $1.55 \mathrm{~m}$ attached to a $1.30 \mathrm{~m}$ long articulated arm that is fixed to the rock (Fig. 5). A $100 \Omega$ potentiometer with 500 turns is used to measure the rotational movement of the wheel. Each turn of the potentiometer corresponds to $3.1 \mathrm{~mm}$, thereby providing a measurement resolution of $\pm 3.1 \mathrm{~mm}$. Consequently, between two measurements, the displacement is measured with a resolution of $\pm 4.2 \mathrm{~mm}$. The daily velocities are extracted from the slope of the curve measured on print graphs. From the graphs, it is possible to count the number of turns. The accuracy of the daily sliding velocity measurements has been assessed to be better than $\pm 1 \mathrm{~cm} \mathrm{~d}^{-1}$. A second potentiometer is set up on the articulation point of the arm. This potentiometer is designed to measure vertical displacement on the cavity roof. In this way, the sudden downward acceleration related to the passage of the wheel on a rock inserted in basal ice can be detected. This happens very rarely and such records have been removed from data.

In addition, the subglacial runoff is monitored in a gallery at $2060 \mathrm{~m}$ a.s.l. during the summer season using a Endress Hauser sensor, which measures the water level in a calibrated channel. The subglacial runoff is measured with an accuracy of $\pm 0.1 \mathrm{~m}^{3} \mathrm{~s}^{-1}$. The measurement frequency is $15 \mathrm{~min}$. Above a value of $13 \mathrm{~m}^{3} \mathrm{~s}^{-1}$, the water is diverted into another conduit and the real runoff is not measured. In our study, maximum daily runoff values have been used. This means that the runoff values exceeding $13 \mathrm{~m}^{3} \mathrm{~s}^{-1}$ are missing. 


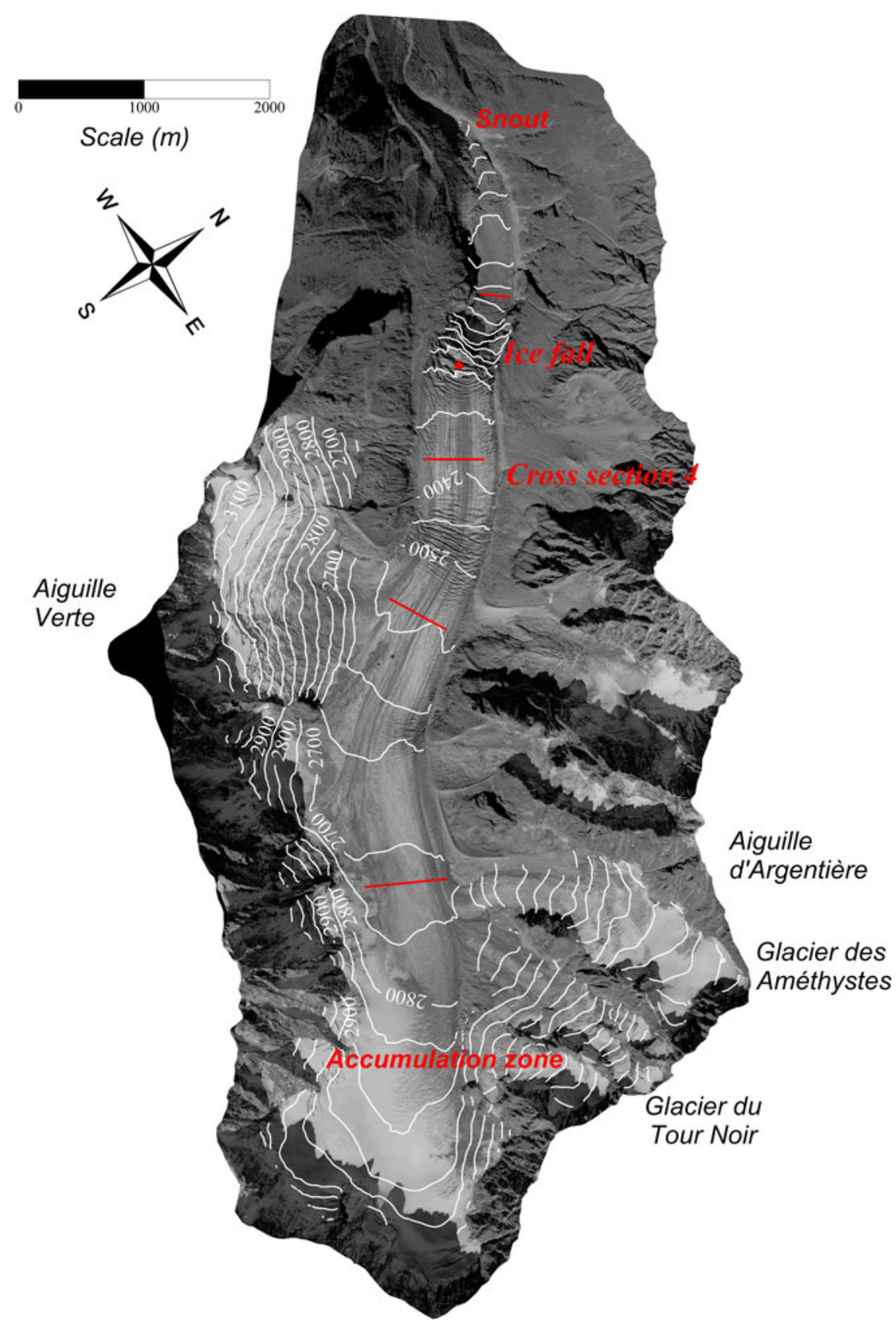

Fig. 1. Map of Argentière glacier. Location of the subglacial cavity (red dot) and cross section No. 4 close to the ice fall. Three other cross sections are shown. The aerial photograph was taken in 2003.

In the area of the subglacial observatory and the tunnels drilled to collect the water, no basal sediments are visible (Vivian, 1980). The bed consists of only bedrock in this region.

Melting is calculated at the altitude of cross section No. 4 using a degree-day model with the meteorological data of

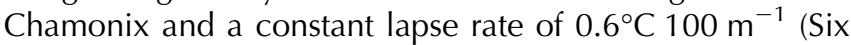
and Vincent, 2014). Rain is obtained from precipitation measurements at Chamonix. Using the same constant lapse rate of $0.6^{\circ} \mathrm{C} 100 \mathrm{~m}^{-1}$, it is taken into account when it is liquid at an altitude of $2400 \mathrm{~m}$.

\section{RESULTS}

\subsection{Annual velocity fluctuations}

As shown in a previous study (Vincent and others, 2009) performed over 50 years of glaciological observations, the response of annual ice thickness to a change in the glacierwide annual mass balance is instantaneous at $2400 \mathrm{~m}$ a.s.l. Indeed, the thickness changes are very similar to the cumulative mass balance changes in this region (Figs 2, 3). Conversely, the reaction time of the thickness changes is delayed by $\sim 3$ years in the lower part of the glacier (Vincent and others, 2009). In the studied region, from the beginning of the series, the thickness increased and reached a peak in 1984 or 1985, simultaneously with the cumulative mass balance. Moreover, the general features of the ice-flow velocity changes at cross section No. 4 are similar and synchronous with thickness changes despite some irregularities in ice-flow velocities on an annual scale.

The surface ice-flow velocity peaked in 1985 simultaneously with thickness and cumulative mass-balance peaks. After 1985, the mass balance, ice thickness and ice-flow velocity all showed a general decreasing trend. Over the last 


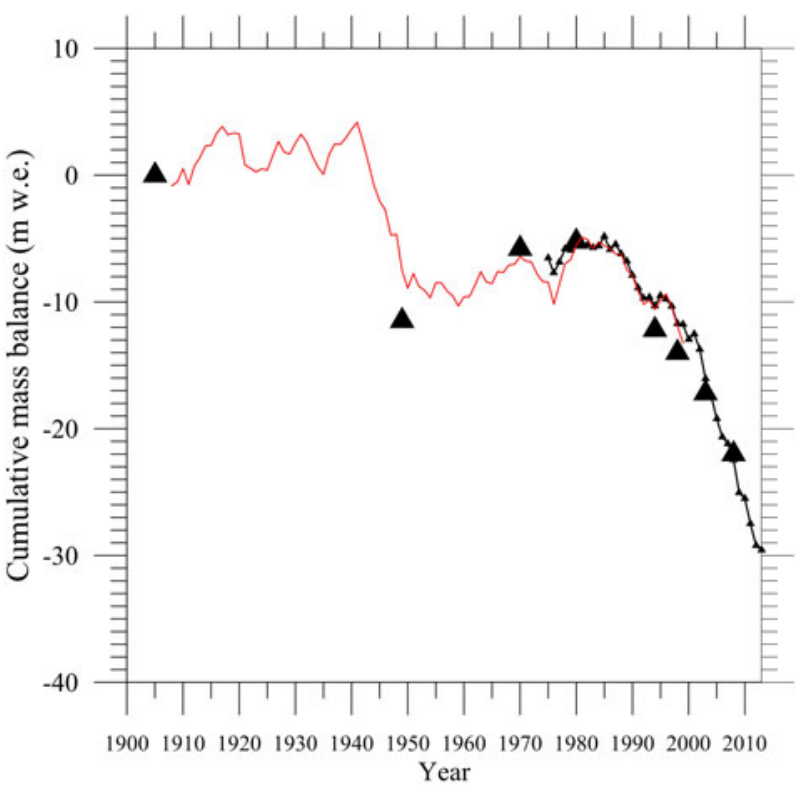

Fig. 2. Cumulative mass balance of the Argentière glacier from direct glaciological measurements (small triangles) and from geodetic mass balance data (large triangles) using aerial photographs (1949, 1970, 1980, 1995, 1994, 1998, 2003 and 2008) and old maps (1905). Between 1905 and 2000, the annual mass balances (red line) were reconstructed using meteorological data.

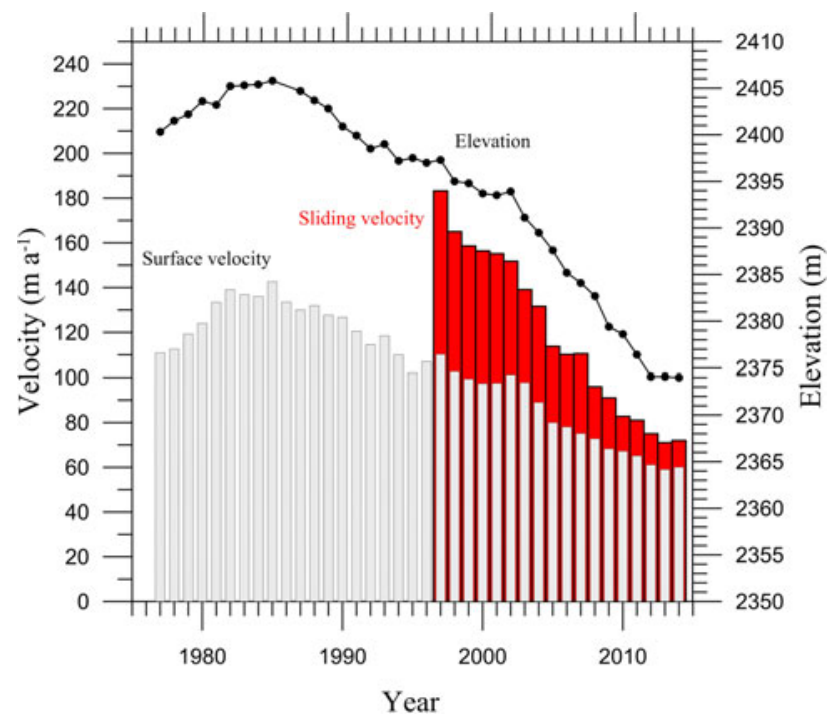

Fig. 3. Ice surface elevation and average surface velocities observed on cross section No. 4 since 1977. Basal velocities observed the subglacial observatory (red bars).

30 years, only 4 years have shown a positive mass balance: 1987, 1993, 1995 and 2001 (Fig. 2). Note that, for each positive mass-balance year, the surface velocity responds with a small acceleration on the same year or the year following the positive mass balance (Fig. 3). A sharp decline in thickness and surface velocity is observed at cross section No. 4 after 1985 (Fig. 3). The sliding velocity, measured in the subglacial cavity located $850 \mathrm{~m}$ downstream, shows the same pattern. Note that the basal sliding velocity is greater than the surface velocity for any given year because the two velocities were not measured at the same location. A clear change is
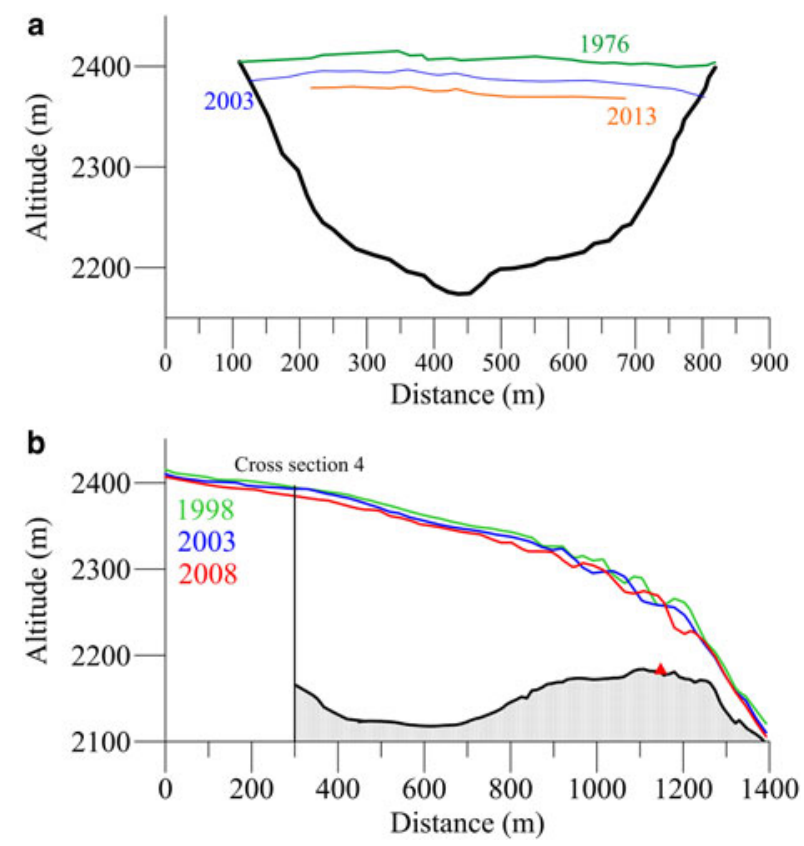

Fig. 4. (a) Cross section No. 4 and (b) the longitudinal section of surface (1998, 2003 and 2008) and bedrock. Location of the subglacial cavity (red triangle).

visible after 2003, with a faster decrease of annual mass balance, thickness and surface ice-flow velocity (Fig. 3). Although the sliding velocity measurement time series is shorter, we observe a change at the same date. Since 1997, sliding velocity and surface velocity decreased by $61 \%$ and $47 \%$, respectively.

Although not measured at the same location, a clear linear relationship was found between annual surface velocity at cross section No. 4 and annual sliding velocity measured in the subglacial observatory (Fig. 6a, black dots) with a regression coefficient of 0.46 and a coefficient of determination $R^{2}=0.98$. We conclude that the increases/decreases of basal sliding velocity observed at the subglacial observatory are roughly twice those of the corresponding surface velocities observed at cross section No. 4.

Moreover, we find a clear relationship between annual basal motion and ice thickness (Fig. 6b). Note that the thickness changes are not known at this location and we assume that they are similar to those measured at cross section No. 4. This assumption is supported by the altitude measurements carried out on the cross section and longitudinal sections over a length of several hundred meters (Fig. 4). Indeed, from the longitudinal section measured from photogrammetric methods, no significant thickness change difference can be seen between cross section No. 4 and the location $500 \mathrm{~m}$ downstream. Note that it is not possible to determine accurately the thickness changes close to the subglacial observatory because it is located in an area with large crevasses. We tested several polynomial functions to fit the relationship between annual basal motion and ice thickness. These tests indicate that a polynomial function with a degree of 2 is sufficient with a RMSD of $3.2 \mathrm{~m} \mathrm{a}^{-1}$ and is not improved significantly with a degree of $3(\mathrm{RMSD}=3.0 \mathrm{~m}$ $\mathrm{a}^{-1}$ ). Moreover, we tested power functions with degrees of 2 and 3. The power function with degree 2 provides poor results $\left(R M S D=12.4 \mathrm{~m} \mathrm{a}^{-1}\right)$. The power function with degree 3 provides better results $\left(\operatorname{RMSD}=4.3 \mathrm{~m} \mathrm{a}^{-1}\right.$ ) but 


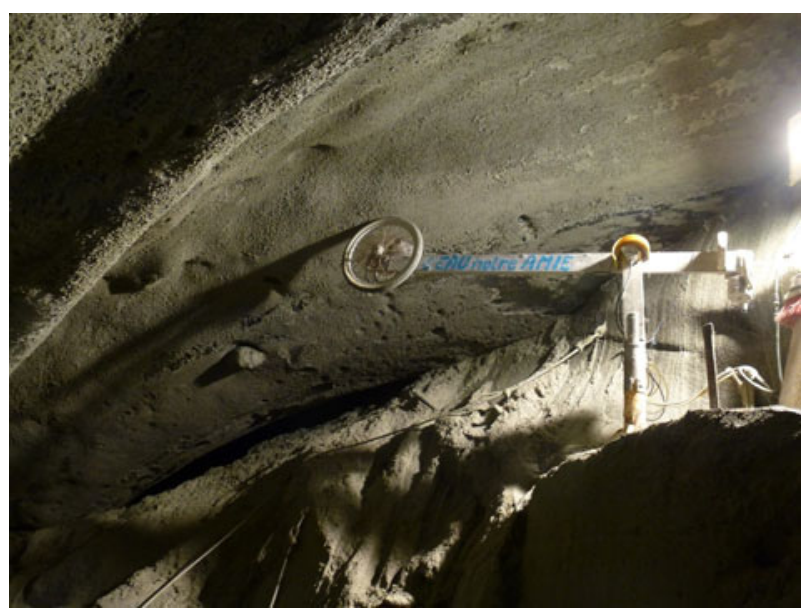

Fig. 5. Subglacial observatory with the bicycle wheel used to measure the basal motion. The articulated arm is $1.30 \mathrm{~m}$ long (Photograph from Luc Moreau).

not as good as the polynomial function (dashed blue line, Fig. 6b). This suggests that simplified relationships to determine the sliding velocities using a power function between sliding velocities and basal shear stress (Oerlemans, 2001) are not really appropriate.

From the surface velocities observed at cross section No. 4 and the calculated deformation, we estimated the sliding velocities at cross section No. 4 (Fig. 6c). The deformation was assessed using a classical approach (Cuffey and Paterson, 2010, p. 310):

$$
u s=u b+\frac{2 A}{n-1} \tau^{n} H
$$

where $H$ is the ice thickness, $u s$ and $u b$ are the velocities at the surface and base, $\tau$ is the shear stress and $n=3$. The creep parameter $A$ is $2.4 \times 10^{-24} \mathrm{~s}^{-1} \mathrm{~Pa}^{-3}$ (Cuffey and Paterson, 2010, p. 75). The longitudinal stress gradients are neglected. Using this approach, the shape factor $F$ is calculated from $W$ which is the half-width divided by the thickness on the center-line (Cuffey and Paterson, 2010, p. 342). The width is $670 \mathrm{~m}$ and the thickness is $210 \mathrm{~m}$. $F$ is 0.62 for a semi-ellipse shape with an uncertainty of \pm 0.1 . The slope is obtained from the surface altitudes of the longitudinal section (Fig. 4). In the vicinity of cross section No. 4, over a distance of $200 \mathrm{~m}$ upstream and downstream, the surface slope is $7.5 \%$ and shows no significant change over the period 1998-2008. From Figure 4, we can assume an uncertainty of $\pm 1 \%$ for the slope. The estimated sliding velocities are shown in Table 1 for the years 1997 and 2013, chosen because they correspond to the maximum and minimum thicknesses, respectively.

The modeled sliding velocity is obtained by subtracting the deformation from the observed surface velocity. These results show that the sliding velocity is therefore the main component $(\sim 90 \%)$ of the surface velocity. The large decrease in the observed surface velocities over the period supports this conclusion. Deformation is driven by thickness and slope and therefore cannot explain this decrease given that the thickness decreased by only $20 \mathrm{~m}$ over this period, while the slope did not change significantly. In addition, whatever the shape factor, the thickness and slope changes cannot explain a velocity change $>5 \mathrm{~m} \mathrm{a}^{-1}$ (Table 1). The
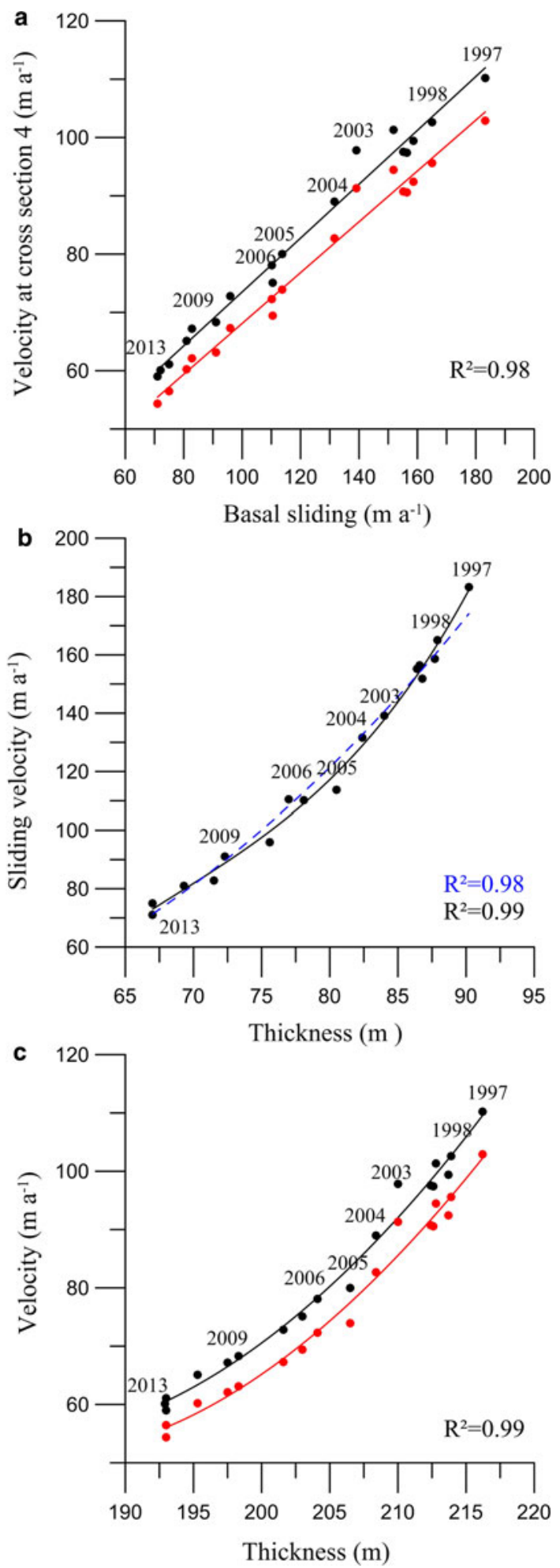

Fig. 6. Relationship between (a) annual surface velocity (black), estimated sliding velocity (red) at cross section No. 4 and sliding velocity measured in the subglacial cavity, (b) sliding velocity measured in the subglacial cavity and thickness. The dashed black line shows a polynomial function with degree 3 while the dashed blue line shows the power function with degree 3, (c) annual surface velocity (black), estimated sliding velocity (red) and thickness at cross section No. 4.

large decline of the surface velocity at cross section No. 4 over the period 1997-2013, equal to $51.4 \mathrm{~m} \mathrm{a}^{-1}$, is therefore explained by the sliding velocity change. The large sliding velocity changes observed in the subglacial observatory confirm the predominant role of sliding. 
Table 1. Deformation and sliding velocity calculated at cross section No. 4 from observed surface velocity, thickness and slope

\begin{tabular}{cccccrc}
\hline & $\begin{array}{l}\text { Thickness } \\
\mathrm{m}\end{array}$ & $\begin{array}{l}\text { Slope } \\
\%\end{array}$ & \multicolumn{2}{c}{$\begin{array}{l}\text { Deformation with } \mathrm{F}=1 \\
\mathrm{~m} \mathrm{a}^{-1}\end{array}$} & $\begin{array}{l}\text { Deformation with } F=0.62 \pm 0.1 \\
\mathrm{~m} \mathrm{a}^{-1}\end{array}$ & \multicolumn{2}{l}{$\begin{array}{l}\text { Observed surface velocity } \\
\mathrm{m} \mathrm{a}^{-1}\end{array}$} & $\begin{array}{l}\text { Estimated sliding velocity } \\
\mathrm{m} \mathrm{a}^{-1}\end{array}$ \\
\hline 1997 & 215 & $7.5 \pm 1$ & 24.8 & $6.0 \pm 0.3$ & 110.2 & $104.2 \pm 3.1$ \\
2013 & 195 & $7.5 \pm 1$ & 16.8 & $4.1 \pm 0.2$ & 58.8 & $54.7 \pm 2.1$ \\
\hline
\end{tabular}

From the relationships shown in Figures $6 \mathrm{~b}$ and c, we conclude that the annual surface and sliding velocity changes are clearly related to the ice thickness changes. The annual fluctuations of ice-flow velocity therefore do not depend on subglacial water runoff at this timescale. Confirmation of this conclusion for other locations would have important implications for numerical modeling. It would mean that numerical models running at an annual timescale do not need any information on the water input or subglacial water pressure. However, for the time being, this eventuality must be treated with caution given that it is based on basal motion measured at one point only. Finally, note the deviation of the year 2003 from the relationship between surface velocity and thickness or basal sliding (Figs 6a, c). The summer 2003 was a very hot summer with heat waves across Europe. The ablation rate was very high. However, this does not explain why the ratio between surface velocity and sliding velocity is higher than expected. Indeed, without any obvious reason, the surface velocity of 2003 is higher than expected.

\subsection{Seasonal velocity fluctuations}

As opposed to the annual fluctuations, the general pattern shown in Figure 7 shows that seasonal ice-flow dynamics are mainly driven by subglacial runoff. Our observations indicate ice-flow acceleration in summer as a result of lubrication of the glacier bed (Cuffey and Paterson, 2010). Continuous sliding velocity measurements carried out since 2000 provide insight into these seasonal fluctuations. In

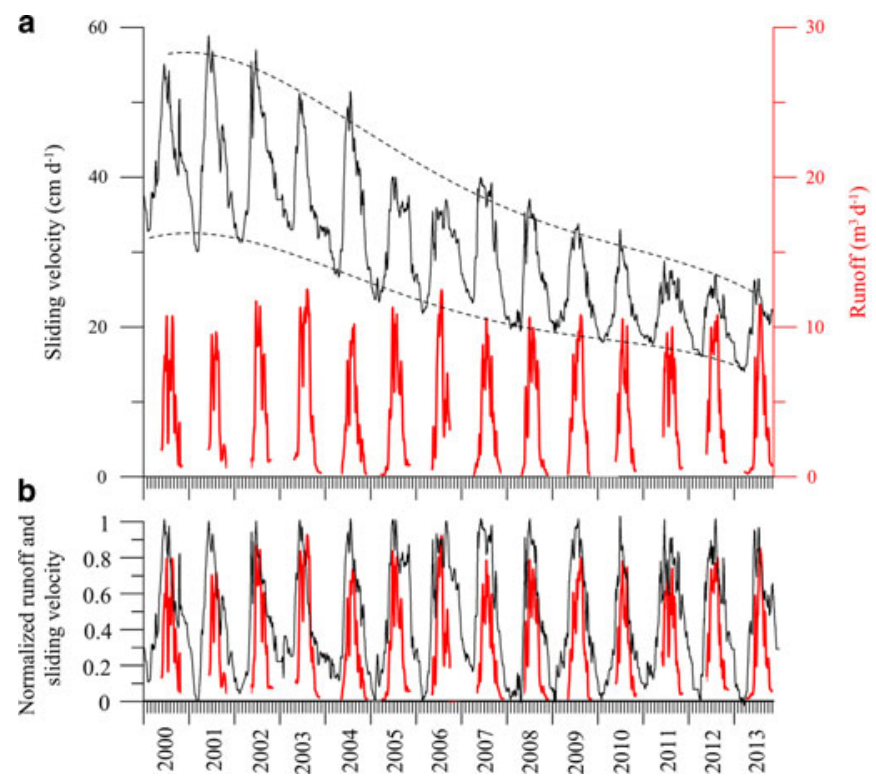

Fig. 7. (a) Measured sliding velocities and subglacial runoff since 2000. The dashed lines show the polynomial functions with a degree 4 using the maximum and minimum annual sliding velocities, (b) normalized runoff and sliding velocity.
Figure $7 \mathrm{a}$, sliding velocities and runoff are plotted using the running averages over $9 \mathrm{~d}$. This indicates that the magnitude of seasonal sliding velocity fluctuations greatly decreased over this period 2000-2013, at the same time as the average annual sliding velocities. There is a clear change after 2004. Note that this marked change occurs after the change in slope of 2003 for mass balance and thickness versus time. On the other hand, the magnitude of seasonal runoff did not change significantly.

From Figure $7 \mathrm{a}$, we can conclude that the sliding velocity peak usually occurs between the 1 June and the 1 July, roughly at the same time as the runoff peak. This observation is in agreement with the modeling results of Pimentel and Flowers (2010). However, as we will see in the next section, there can be significant time differences between the runoff peak and the sliding velocity peak. The minimum sliding velocity occurs between the 1 February and the 1 April. Although no measurements of runoff are available during this season, we know that runoff is very low during this period of the year. To allow a closer comparison between runoff and basal motion, the sliding velocities were normalized. For this purpose, the minimum of the hydrological year was subtracted from each sliding velocity value and the result divided by the range over the year (Fig. 7b). Runoff was normalized by dividing the runoff by the maximum runoff value, i.e. $13 \mathrm{~m}^{3} \mathrm{~s}^{-1}$.

From this comparison, at a seasonal scale, the sliding velocity clearly increases long before the increase in runoff and continues to decrease after the runoff has fallen back to minimum winter values. We conclude that there is a complicated relationship between sliding velocity and runoff at a seasonal scale. On one hand, the years with very negative mass balances $(2003,2009,2011)$ and high runoff do not show very large sliding velocities. In line with this, the sliding velocity range of 2003, for which summer ablation was exceptional, is weak in comparison with the previous and following years (Fig. 7a). However, the sliding velocity in the winter and spring of 2003 remains high, driven by the water input related to the strong ablation at the beginning of the melt season. On the other hand, the years with positive or less negative mass balance (2001, 2007, 2010 and 2013) do not show low sliding velocities. Similarly, the only year with a positive mass balance (2001) shows a high sliding velocity.

\subsection{Intra-seasonal sliding velocity fluctuations and subglacial runoff}

Daily sliding velocities, subglacial runoff and melting plus rain are plotted in Figure 8 for some selected summer seasons during which runoff measurements started early in spring. We selected the year 2003 with a very negative annual mass balance $\left(-2.31 \mathrm{~m}\right.$ w.e $\left.\mathrm{a}^{-1}\right)$, the year 2008 with

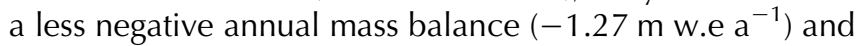
the year 2013 with a still smaller negative annual mass 

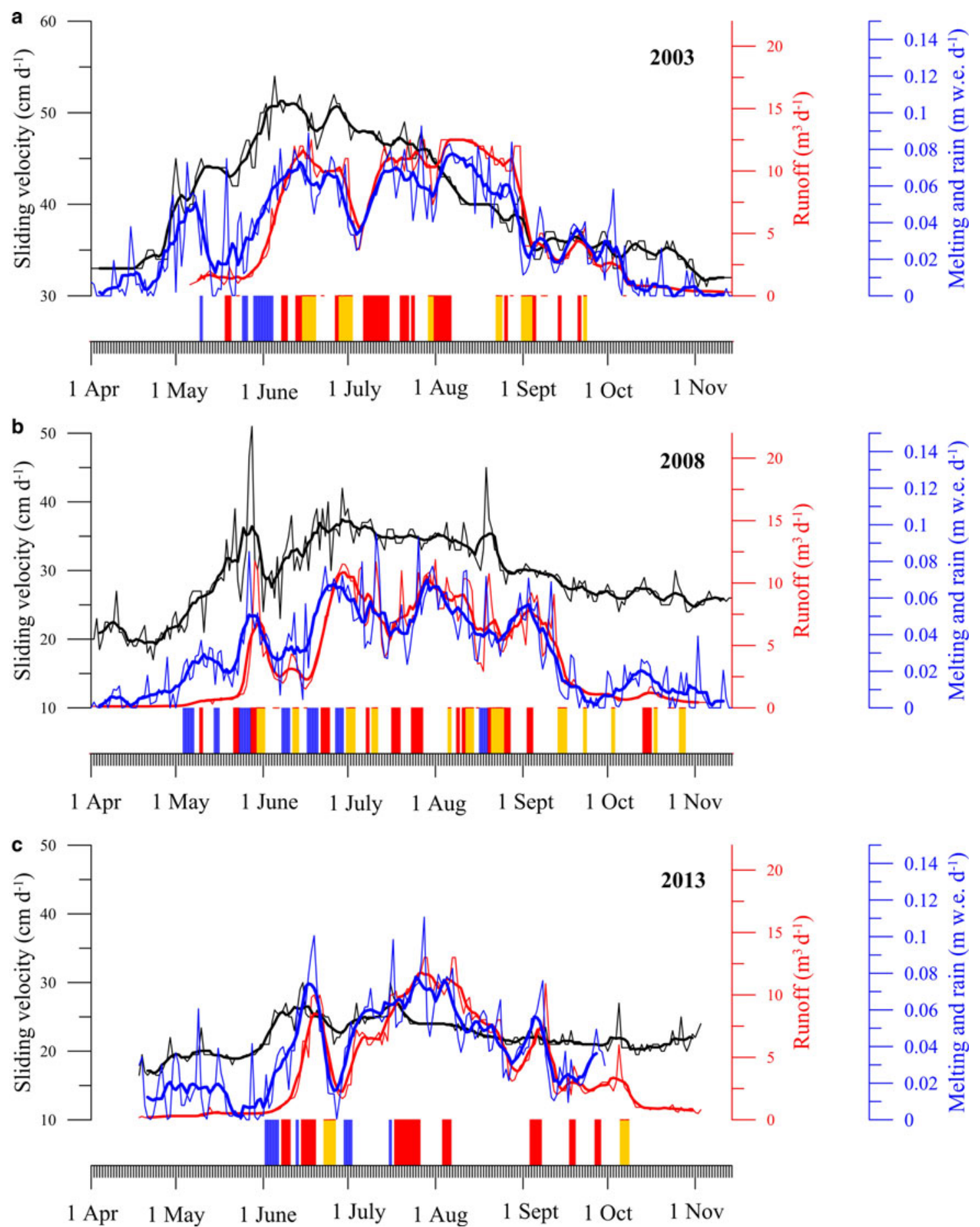

Fig. 8. Sliding velocities (black line), subglacial runoff (red line) and meltwater plus rain (blue line) for melt seasons 2003, 2008 and 2013. The blue bars at the bottom of each graph mark simultaneous increases of runoff and sliding. The red bars correspond to increasing runoff with decreasing sliding. The yellow bars mark simultaneous decreases of runoff and sliding. The events with decreasing runoff and increasing sliding are rare and not shown here for the sake of clarity. To take into account the uncertainties of the runoff and sliding measurements, slopes $<0.15 \mathrm{~m}^{3} \mathrm{~s}^{-2}$ and $1.5 \mathrm{~cm} \mathrm{~d}^{-1}$ for runoff and sliding velocity respectively have been removed from the analysis.

balance $\left(-0.42 \mathrm{~m}\right.$ w.e $\left.\mathrm{a}^{-1}\right)$. The other years are shown in the Supplementary material. Note that the maximum daily values of runoff are reported here. The thick line corresponds to the 7 $\mathrm{d}$ moving average. The values of melt and rain should be considered as proxy data, reaching the subglacial network, given that subglacial water can come from upper zones following complicated englacial and subglacial pathways. Although the calculated meltwater and liquid precipitation results from a degree-day model, it seems to be in relatively good agreement with the runoff observed in the subglacial observatory (Fig. 8). The advantage of melt/rain estimations is that they can be used to complete the runoff series for periods with no measurements (beginning of spring) for a qualitative analysis. However, we use the runoff data in the following quantitative analysis.

Except for 2001, for which runoff data are missing before June, these observations indicate an increase in sliding velocity preceding the runoff increase (Supplementary material). Generally, the first sliding velocity peak occurs in June, before the peak of melt/rain or runoff. This is clear in 2001, 
2003, 2007, 2010, 2011 and 2013 and the delay of the runoff peak ranges from several to $20 \mathrm{~d}$. On the other hand, in 2005, the peaks are simultaneous. In 2012, no clear comparison can be made given that the sliding velocity does not show a clear maximum at the beginning of the summer season. Over the whole period, the maximum of basal velocity is generally reached in June although the runoff peak is reached in July or August. For a quantitative analysis, we calculated the rate of change of the runoff and sliding velocity over $5 \mathrm{~d}$ averages. This time span was chosen to take into account the response time of sliding velocity to the change of runoff (Dalban-Canassy and others, 2012).

As can be seen in Figure 8, simultaneous increases of runoff and sliding velocity occurred mainly in May and June and at the end of the melt season after the 1 September (blue bars). For these periods, the runoff is generally low and an increase of runoff leads to an increase of subglacial water pressure (see section 4 ). In the middle of the summer season (July and August), no obvious relationship between runoff and sliding velocity can be seen. Generally, during this period, an increase of runoff does not lead to an increase of sliding velocity. Many events with increasing runoff and decreasing sliding are reported in July and August (red bars). This indicates that the conduits have grown to a sufficient size, which means that basal water pressures and sliding velocity are no longer sensitive to the water amount coming from the surface. After September, following a large decrease of runoff and basal motion, a sudden increase of runoff leads to an increase of sliding velocity. This is obvious in 2000, 2001, 2004, 2005, 2007, 2009, 2010, 2011 and 2012. The same analysis was performed using 9 and $7 \mathrm{~d}$ moving averages. The results are not significantly different.

\subsection{Analysis of large sudden accelerations}

Some events marked by large acceleration can last only few hours or days following a period of large melting or rain or both. To analyze these sudden accelerations, we selected events with a daily sliding velocity higher than $115 \%$ of the moving average velocity. We found 19 such events between 2000 and 2013 (see Supplementary material). Six events occurred in May without an increase of runoff. Thirteen events are related to large increases of runoff and occurred between midAugust and the beginning of November, except for two events that occurred on the 19 May 2006 and 14 July 2012. These observations tend to show that, at the beginning of melt season, basal motion is very sensitive to water input and can increase considerably with only a small amount of water input. Between the 1 July and 15 August, sudden accelerations are very rare. This suggests that the conduits have reached a large size and can accommodate a large increase in water input. Conversely, at the end of the melt season, after midAugust, large accelerations are systematically related to large runoff increases.

We analyzed one of these events in detail (Fig. 9). For this, we selected an acceleration in 2014 for which measurements over time intervals of 15 min were available. In addition, for this period, precipitation data were available in the vicinity of the glacier, from a meteorological station located $1 \mathrm{~km}$ from the subglacial observatory (D. Six, 2015, personal communication). The storm that occurred on the 26 August 2014 provided $80 \mathrm{~mm}$ of rain between 03:00 and 17:15. This led to a

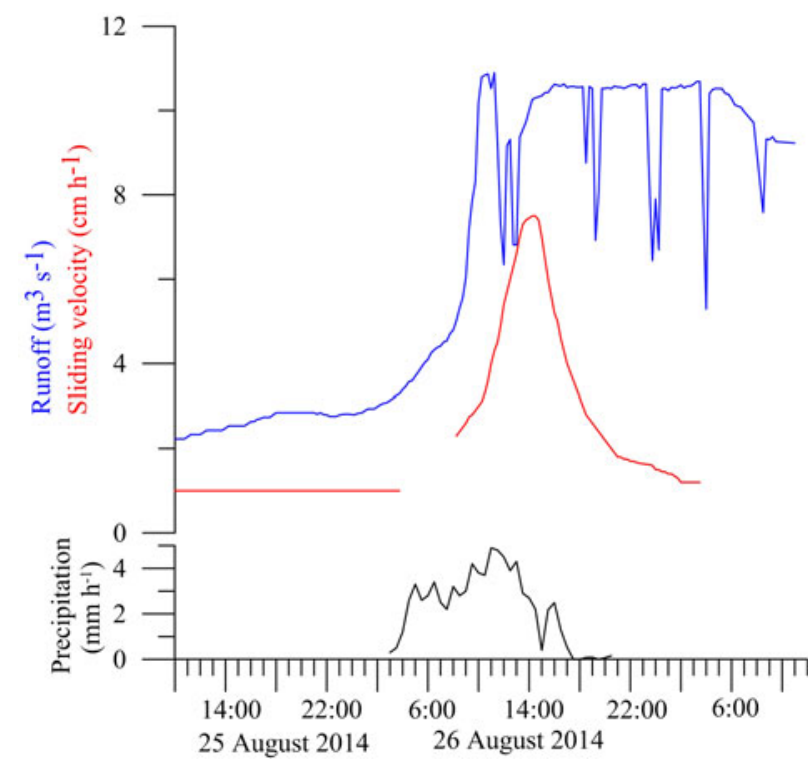

Fig. 9. Sliding velocities (red), subglacial runoff (blue) and precipitation (black) during the storm event of the 26 August 2014.

sharp increase in runoff from 3 to $10.9 \mathrm{~m}^{3} \mathrm{~s}^{-1}$ between 03:00 and 10:30. Unfortunately, the instrument used to measure sliding velocity failed between 04:15 and 08:00. However, measurements indicate that the sliding velocity was $1 \mathrm{~cm}$ $\mathrm{h}^{-1}$ at 04:00 and $2.3 \mathrm{~cm} \mathrm{~h}^{-1}$ at 08:15. The sliding velocity reached a peak of $7.5 \mathrm{~cm} \mathrm{~h}^{-1}$ at $14: 15$, while the runoff peak reached at 10:30. This suggests that sliding velocity reacted almost instantaneously, with a $0-4 \mathrm{~h}$ delay, once the water pressure counteracted the pressure due to the weight of the glacier. This single event contributed to a displacement of $0.29 \mathrm{~m}$. Note the large and sudden fluctuations in runoff, after 10:30. These apparent dips are due to the intermittent diversion of water upstream of the runoff measurement instrument by an automatic system designed to flush rocks from the gravel trap when the trap is full. Note the large decrease of sliding velocity just after the velocity peak has been reached, although the runoff rate is maintained at its maximum for about $18 \mathrm{~h}$ after the runoff peak has been reached. Shortly after the rainfall and large water input, the sliding rate returns to its value preceding the storm.

These results are in good agreement with the results of a previous study carried out by Vivian and Zumstein (1973) from water pressure measurements performed in September 1968 in a gallery in the vicinity of the subglacial observatory. These authors showed that the increases of runoff and water pressure were almost simultaneous.

\section{DISCUSSIONS}

Our study shows that annual surface velocity is clearly related to basal sliding and that more than $90 \%$ of the surface motion is due to basal sliding. This is consistent with the findings of Raymond (1971), Hooke and others (1992) and Blake and others (1994) indicating that sliding accounts for more than $80 \%$ of the surface speed at the center of the glacier. Our results suggest that annual velocity (surface and sliding) variations are driven by thickness changes.

Except for some extensive field studies like the Unteraargletscher observations in Switzerland (Huss and 
others, 2007) or Hintereisferner observations in Austria (Span and Kuhn, 2003), few measurement datasets relative to iceflow velocities are available over several decades. Based on ice flow velocities measured over $50 \mathrm{a}$ at Hintereisferner, Span and Kuhn (2003) showed that the change in annual velocity is determined by a recession term containing the velocity of the previous year and a driving term that is proportional to the annual load of ice in the accumulation area. In other words, they found that the annual velocity change is driven by the mean glacier-wide mass balance of the accumulation area of the current year. Here, we found that annual velocity changes are related to thickness changes. If this conclusion is valid for the entire glacier, it would mean that numerical models of ice flow running at an annual timescale do not need any information on water input or subglacial water pressure. However, this conclusion cannot be generalized given that, on other glaciers, annual ice-flow velocity changes are not related to thickness changes only, given that basal sliding seems to play a significant role and is not related to thickness changes (Vincent and others, 2000).

From the analysis of the seasonal ice-flow velocities, we found a clear relationship between sliding velocity and runoff, i.e. similar oscillations of sliding velocity and runoff. However, looking closer, we found that the sliding velocity increases largely before the increase in runoff at the beginning of the melt season and continues to decrease after the runoff falls back to minimum winter values. These observations are in agreement with the classical understanding of subglacial processes (e.g. Pimentel and Flowers, 2010). At the beginning of the melt season, discharge from the distributed system dominates. The water pressure increases and promotes basal motion. These observations are in agreement with other experimental studies (e.g. Nienow and others, 1998, 2005; Mair and others, 2002, 2003; Sugiyama and Gudmunsson, 2004) and model studies (Pimentel and Flowers, 2010; Schoof, 2010; Werder and others, 2013; Hoffman and Price, 2014). During this phase, the observed sliding velocity increase is related to a runoff increase. While runoff and water pressures increase in May, the glacier markedly accelerates from its quiescent baseline, with basal speeds generally reaching a peak in June. The first sliding velocity peak occurs in June before the runoff peak. The delay of the runoff peak ranges from several to $20 \mathrm{~d}$, except in 2005 when the peaks are simultaneous. However, our results seem to show a slightly different behavior compared with the study carried out on Kennicott glacier (Bartholomaus and others, 2008). Although, the basal motion was not measured directly, this previous study showed that peaks in basal speed occurred shortly ( $2 \mathrm{~h}$ ) after the time of the greatest rate of increase in water storage. The efficiency of the drainage system could also depend on the snowline that migrates over the melt season given that the snowpack can delay inputs of meltwater into the subglacial system (Nienow and others, 2005). However, the bare ice of Argentière is exposed early at the beginning of the melt season (May) and water storage in snow is negligible. Consequently, in the case of Argentière, the snow line migration has probably a weak influence on the storage of water in firn and on the delay between melting and runoff.

As we enter the spring season, the distributed drainage system becomes more efficient thanks to the opening of cavities (Hoffman and Price, 2014). This causes the end of the spring acceleration event. In this way, the sustained water input does not lead to continued rapid motion. In addition, the glacier drainage network evolves significantly with the fast (conduit) system growing at the expense of the slow distributed system (Iken and Bindschaldler, 1986; Nienow and others, 1998, 2005; Hewitt and Fowler, 2008; Schoof, 2010). In this way, large amounts of water give rise to channelized flow (Pimentel and Flowers, 2010; Hoffman and Price, 2014). This is the so-called 'spring transition'. In our study, basal water pressure measurements were not available. We used runoff change as a proxy of water pressure. Although the water pressure is not related to runoff, we assume that the water pressure depends on the runoff increase when this value exceeds a critical value. Using this approach, we found that simultaneous increases ( $5 \mathrm{~d}$ average) in runoff and sliding velocity occurred mainly before the spring transition. These observations are in agreement with a study carried out on Triftgletscher (Dalban-Canassy and others, 2012), in which the authors found that the surface motion was driven significantly by runoff changes at a timescale of $2-3 \mathrm{~d}$.

Once the conduits have grown to a sufficient size, such that they discharge most of the subglacial water, basal water pressure and consequently basal motion decreases consistent with theoretical studies (Pimentel and Flowers, 2010; Schoof, 2010). After the velocity peak has been reached, basal water pressures and sliding velocity are generally no longer related to the amount of water coming from the surface except for some events (see below). For this reason, we observe, in the midsummer of the melt season, a decrease of sliding velocity despite an increase of runoff (Fig. 8 and the Supplementary material). In the same way, Sugiyama and Gudmunsson (2004) show that although glaciers slide most rapidly at times of high water pressure, they slide faster when water pressures are rising than when the pressures are declining.

At the end of the melt season, with large conduits, creepclosure overtakes melt-opening and the conduit cross-sectional area decreases (Pimentel and Flowers, 2010). In this way, after midAugust, we observed that an increase of water input can lead to a new basal water pressure increase and, consequently, an acceleration of the glacier (Fig. 8 and the Supplementary material). Drainage evolution therefore plays a key role in the acceleration (Fudge and others, 2009).

\section{CONCLUSIONS}

Our present study shows that the thickness and ice-flow velocity changes measured at cross section No. 4 are very similar to cumulative mass balance changes. It is in agreement with a previous study (Vincent and others, 2009), which showed that this glacier reacts very quickly to surface mass balance changes. This previous study indicated that velocity fluctuations are synchronous over the entire study area. Thickness and ice-flow velocity changes are therefore mainly driven by surface mass balance changes.

Moreover, we have found a clear relationship between annual surface velocity, basal sliding velocity and ice thickness. We conclude that, at an annual timescale, the fluctuations of the ice-flow velocity do not depend on subglacial water runoff changes. In addition, we have found that surface velocity is clearly related to basal sliding and that more than $90 \%$ of the surface motion is due to basal sliding. Our results suggest that annual velocity (surface and sliding) variations are driven by thickness changes. 
The analysis of the seasonal ice-flow velocities indicates a large decrease of the seasonal sliding magnitude with time over the last decades, between 2000 and 2013. This decrease is concomitant with the annual velocity decrease. Generally, at the seasonal timescale, we found a clear relationship between sliding and runoff, i.e. similar oscillations of sliding velocity and runoff. However, we found that the sliding velocity increases greatly before the increase in runoff at the beginning of the melt season and continues to decrease after the runoff falls back to minimum winter values.

The analysis of the intra-seasonal sliding velocity fluctuations indicates a complex pattern. For this analysis, we studied the runoff change as a proxy of water pressure. We found that simultaneous increases ( $5 \mathrm{~d}$ average) in runoff and sliding velocity occurred mainly before the spring transition. Conversely, after the velocity peak has been reached, sliding velocity is generally no longer related to the amount of water coming from the surface except for some events. These rare events marked by large acceleration can last only few hours or days following a period of large melting or rain or both.

An analysis of large accelerations showed that most such events occurred between midAugust and the beginning of November and were always related to large increases of runoff. The other such events occurred in May without increases of runoff. The detailed analysis of the acceleration of the 26 August 2014 following a storm indicated that, the sliding velocity reacted almost instantaneously, with a 0-4 $h$ delay after the increase of runoff.

In conclusion, these measurements from the subglacial observatory combined with the supraglacial measurements offer a valuable dataset for future numerical studies aimed at investigating the hydromechanical processes that drive the sliding velocity.

\section{SUPPLEMENTARY MATERIAL}

The supplementary material for this article can be found at http://dx.doi.org/10.1017/jog.2016.35.

\section{ACKNOWLEDGEMENTS}

This study was funded by Electricité Emosson SA (hydroelectric company), Observatoire des Sciences de I'Univers de Grenoble (OSUG) and Institut des Sciences de I'Univers (INSU) in the framework of the French 'GLACIOCLIM (Les GLACiers comme Observatoire du CLIMat)' project. We thank Delphine Six who provided precipitation data from the automatic weather station of Argentière glacier. We thank André Pahud and Jean Marie Nicolas who took part in setting up the field instruments. We are indebted to O. Gagliardini for reading the manuscript carefully and helping to improve it. We thank Neil Iverson and an anonymous reviewer whose thorough comments improved the quality of the manuscript. We are grateful to $\mathrm{H}$. Harder for reviewing the English.

\section{REFERENCES}

Alley RB (1989) Water-pressure coupling of sliding and bed deformation, I, Water system. J. Glaciol., 35, 108-139

Amundson J, Truffer M and Lüthi M (2006) Time-dependent basal stress conditions beneath Black Rapids Glacier, Alaska, USA, inferred from measurements of ice deformation and surface motion. J. Glaciol., 52, 178, 347-357 (doi: 10.3189/ 172756506781828593)

Bartholomaus TC, Anderson RS and Anderson SP (2008) Response of glacier basal motion to transient water storage. Nat. Geosci., 1(1), 33-37 (doi: 10.1038/ngeo.2007.52)

Bartholomew I and 5 others (2010) Seasonal evolution of subglacial drainage and acceleration in a Greenland outlet glacier. Nat. Geosci., 3, 408-411 (doi: 10.1038/ngeo863)

Bartholomew I and 5 others (2012) Short-term variability in Greenland Ice Sheet motion forced by time-varying meltwater drainage: implications for the relationship between subglacial drainage system behavior and ice velocity. J. Geophys. Res., 117, F03002 (doi: 10.1029/2011JF002220)

Bindschadler RA (1983) The importance of pressurized subglacial water in separation and sliding at the glacier bed. J. Glaciol., 29, 3-19

Björnsson H (1998) Hydrological characteristics of the drainage system beneath a surging glacier. Nature, 395, 771-774

Blake EW, Fischer UH and Clarke GKC (1994) Direct measurement of sliding at the glacier bed. J. Glaciol., 40, 595-599

Clarke GKC (1996) Lumped-element analysis of subglacial hydraulic circuits. J. Geophys. Res., 101, 17547-17559

Clarke GKC (2005) Subglacial processes. Annu. Rev. Earth Planet. Sci., 33, 247-276 (doi: 10.1146/annurev.earth.33.092203.122621)

Cohen DR, Hooke RL, Iverson NR and Kohler J (2000) Sliding of ice past an obstacle at Engabreen, Norway. J. Glaciol., 46, 599-610

Creyts TT and Schoof CG (2009) Drainage through subglacial water sheets. J. Geophys. Res., 114, F04008 (doi: 10.1029/2008JF001215)

Cuffey K and Paterson WSB (2010) The physics of glaciers, 5th edn. Massachusetts Academic Press, Burlington

Dalban-Canassy P, Faillettaz J, Walter F and Huss M (2012) Seismic activity and surface motion of a steep temperate glacier: a study on Triftgletscher, Switzerland. J. Glaciol., 58(209), 513-528 (doi: 10.3189/2012JoG11J104)

Engelhardt H and Kamb B (1998) Basal sliding of Ice Stream B, West Antarctica. J. Glaciol., 44, 223-230

Fischer UH and Clarke GKC (1994) Ploughing of subglacial sediment. J. Glaciol., 40, 97-106

Flowers GE and Clarke GKC (2002) A multicomponent coupled model of glacier hydrology -1 . Theory and synthetic examples. J. Geophys. Res., 107(B11), 2287 (doi: 10.1029/2001JB001122)

Fountain AG and Walder JS (1998) Water flow through temperate glaciers. Rev. Geophys., 36, 299-328

Fowler AC (1987) Sliding with cavity formation. J. Glaciol., 33, 255267

Fudge TJ, Harper JT, Humphrey NF and Pfeffer WT (2009) Rapid glacier sliding, reverse ice motion and subglacial water pressure during an autumn rainstorm. Ann. Glaciol., 50(52), 101-108 (doi: 10.3189/172756409789624247)

Hantz D and Lliboutry L (1983) Waterways, ice permeability at depth and water pressures at glacier d'Argentière, French Alps. J. Glaciol., 29(102), 227-238

Harper JT, Humphrey NF, Pfeffer WT and Lazar B (2007) Two modes of accelerated glacier sliding related to water. Geophys. Res. Lett., 34, L12503 (doi: 10.1029/2007GL030233)

Hewitt IJ and Fowler AC (2008) Seasonal waves on glaciers. Hydrol. Process., 22, 3919-3930

Hoffman M and Price S (2014) Feedbacks between coupled subglacial hydrology and glacier dynamics. J. Geophys. Res. Earth Surf., 119, 414-436 (doi: 10.1002/2013JF002943)

Hooke RL, Pohjola VA, Jansson P and Kohler J (1992) Intra-seasonal changes in deformation profiles revealed by boreholes studies, Storglaciären, Sweden. J. Glaciol., 38, 130, 348-358

Hubbard A, Blatter H, Nienow P, Mair D and Hubbard B (1998) Comparison of a three-dimensional model for glacier flow with field data from haut Glacier d'Arolla, Switzerland. J. Glaciol., 44, 147, 368-378

Huss M, Sugiyama S, Bauder A and Funk M (2007) Retreat scenarios of Unteraargletscher, Switzerland, using a combined ice-flow mass-balance model. Arct. Antarct. Alp. Res., 39(3), 422-431 
Iken A (1981) The effect of the subglacial water pressure on the sliding velocity of a glacier in an idealized numerical model. J. Glaciol., 27, 407-421

Iken A and Bindschaldler RA (1986) Combined measurements of subglacial water pressure and surface velocity of Findelengletscher, Switzerland: conclusions about drainage system and sliding mechanism. J. Glaciol., 32(110), 101-119

Iken A, Röthlisberger H, Flotron A and Haeberli W (1983) The uplift of Unteraargletscher at the beginning of the melt season- a consequence of water storage at the bed? J. Glaciol., 29(101), 28-47

Iverson NR and 7 others (2003) Effects of basal debris on glacier flow. Science, 301, 81-84

Jansson P, Kohler J and Pohjola VA (1996) Characteristics of basal ice at Engabreen, northern Norway. Ann. Glaciol., 22, 114-120

Kamb B (1970) Sliding motion of glaciers: theory and observation. Rev. Geophys., 8, 673-728

Kamb B (1987) Glacier surge mechanism based on linked cavity configuration of the basal water conduit system. J. Geophys. Res., 92(B9), 9083-9099

Lefeuvre PM, Jackson M, Lappegard G and Hagen JO (2015) Interannual variability of glacier basal pressure from a 20 year record. Ann. Glaciol., 56(70), 33-44 (doi: 10:3189/2015AoG70A019)

Lliboutry L (1968) General theory of subglacial cavitation and sliding of temperate glaciers. J. Glaciol., 7(49), 21-58

Mair D, Nienow P, Willis I and Sharp MJ (2001) Spatial patterns of glacier motion during a high-velocity event: Haut Glacier d'Arolla, Switzerland. J. Glaciol., 47, 156, 9-20

Mair D, Nienow P, Sharp MJ, Wohlleben T and Willis I (2002) Influence of subglacial drainage system evolution on glacier surface motion: Haut glacier d'Arolla, Switzerland. J. Geophys. Res., 107(B8), 2175 (doi: 10.1029/2001JB000514)

Mair D and 5 others (2003) Hydrological controls on patterns of surface, internal and basal motion during three "spring events": haut Glacier d'Arolla, Switzerland. J. Glaciol., 49, 555-567

Moreau L (1995) Comportement d'un glacier tempéré sur son lit rocheux. (thesis, University of Grenoble, Institut de Géographie Alpine, Grenoble)

Nienow PW, Sharp M and Willis I (1998) Seasonal changes in the morphology of the subglacial drainage system, Haut glacier d'Arolla, Switzerland. Earth Surf. Process. Landforms, 23(9), 825-843

Nienow PW and 6 others (2005) Hydrological controls on diurnal ice flow variability in valley glaciers. J. Geophys. Res., 110 (doi: 10.1029/2003JF000112)

Nye JF (1973) Water at the bed of a glacier. In Proceedings of the Cambridge Symposium 1969, IASH, no. 95, 189-194

Oerlemans J (2001) Glacier and climate change. Balkema AA, Lisse eds, The Netherlands, $148 \mathrm{pp}$

Pimentel S and Flowers GE (2010) A numerical study of hydrologically driven glacier dynamics and subglacial flooding. Proc. R. Soc. London, Ser. A., 2011, 467, 537-558 (doi: 10.1098/rspa.2010.0211)
Raymond CF (1971) Flow in a transverse section of Athabasca glacier, Alberta, Canada. J. Glaciol., 10(58), 55-84

Reynaud M (1959) Prospection au glacier d'Argentière. Société Hydrotechnique de France, Section Glaciologie, Paris

Rignot E and Kanagaratnam P (2006) Changes in the velocity structure of the Greenland Ice Sheet. Science, 311, 986-990

Röthlisberger $\mathrm{H}$ (1972) Water pressure in intra- and subglacial channels. J. Glaciol., 11(62), 177-203

Ryser C and 7 others (2014) Sustained high basal motion of the Greenland ice sheet revealed by borehole deformation. J. Glaciol., 60(222) (doi: 10.3189/2014JoG13J196)

Schoof C (2010) Ice-sheet acceleration driven by melt supply variability. Nature, 468, 803-806 (doi: 10.1038/nature09618)

Shoemaker EM (1986) Subglacial hydrology for an ice sheet resting on a deformable aquifer. J. Glaciol., 32(110), 20-30

Six D and Vincent C (2014) Sensitivity of mass balance and equilibrium-line altitude to climate change in the French Alps. J. Glaciol., 60, 223 (doi: 10.3189/2014JoG14J014)

Span N and Kuhn M (2003) Simulating annual glacier flow with a linear reservoir model. J. Geophys. Res., 108(D10), 4313 (doi: 10.1029/2002JD002828)

Sugiyama S and Gudmunsson GH (2004) Short-term variations in glacier flow controlled by subglacial water pressure at Lauteraargletscher, Bernese Alps, Switzerland. J. Glaciol., 50(170), 353-363

Vincent C, Vallon M, Reynaud L and Le Meur E (2000) Dynamic behaviour analysis of glacier de Saint Sorlin, France, from 40 years of observations, 1957-1997. J. Glaciol., 46, 154, 499-506

Vincent C, Soruco A, Six D and Le Meur E (2009) Glacier thickening and decay analysis from fifty years of glaciological observations performed on Argentière glacier, Mont-Blanc area, France. Ann. Glaciol., 50, 73-79

Vivian R (1975) Les glaciers des Alpes occidentales, étude géographique. (thesis, University of Grenoble, Institut de Géographie Alpine, Grenoble)

Vivian R (1980) The nature of the ice-rock interface: the results of investigation on $20000 \mathrm{~m}^{2}$ of the rock bed of temperate glaciers. J. Glaciol., 25, 92, 267-277

Vivian R and Zumstein J (1973) Hydrologie sous-glaciaire au glacier d'Argentière (Mont Blanc, France). In Union Géophysique Internationale. Association Internationale d'Hydrologie Scientifique. Commission de Neiges et Glaces. Symposium on the Hydrology of Glaciers, Cambridge, 7-13 September 1969, no. $95,53-64$

Walder JS (1986) Hydraulics of subglacial cavities. J. Glaciol., 32 (112), 439-445

Weertman J (1972) General theory of water flow at the base of a glacier or ice sheet. Rev. Geophys. Space Phys., 10(1), 287-333

Werder MA, Hewitt IJ, Schoof CG and Flowers G (2013) Modeling channelized and distributed subglacial drainage in two dimensions. J. Geophys. Res., 118, 1-19 (doi: 10.1002/jgrf.20146) 